\title{
Analysis of The Need for Accelerated Learning Model Based on Double Intelligence in Learning Arts of Middle Music
}

\author{
Venny Ribka Wisudarni $\mathbf{S}^{1}$, Harun Sitompul ${ }^{2}$, Julaga Situmorang ${ }^{3}$ \\ 1,2,3Universitas Negeri Medan, Indonesia \\ Email: vennyribka85@gmail.com
}

\begin{abstract}
This study aims to analyze the needs of the development of accelerated learning models based on multiple intelligences. The study was conducted by survey method in 9 (nine) Junior High Schools in Serdang Bedagai Regency. The research subjects were 18 class teachers who taught Art learning. The object studied is the response of the principal and teachers to the development of accelerated learning models based on multiple intelligences, the tendency of teachers to apply thematic models in learning in schools, student reasoning, and student character. Data collected by interview, questionnaire, observation, and test. Data were analyzed descriptively. The analysis shows that (1) school principals have not yet fostered the development of accelerated learning learning models, so they support development efforts, (2) teachers have not yet developed and used thematic models, so they support and express readiness to be involved in development, (3) learning models used by teachers so far there have been no indications leading to accelerated learning models based on multiple intelligences Keywords: learning model; accelerated learning; multiple intelligences
\end{abstract}

\section{Introduction}

Education and curriculum are very closely related, education is the goal or goal that is achieved or can be called a long-term goal to realize students who excel and excel, if analogically education is a major part and in it there is curriculum as the second largest part in which the curriculum in here acts as a program or system used for the achievement of an education.

The curriculum that applies in the Indonesian education system is the 2013 curriculum. This curriculum is a curriculum that is still being applied by the government to replace the 2006 Curriculum (Ion Genesis Situmorang, Retno Dwi Suyanti, 2010).

The curriculum 2013 was developed with improvements to the following mindset: (a) Teacher-centered learning patterns become learner-centered learning. Students must have choices on the material being studied to have the same competencies, (b) One-way learning patterns (teacher-student interaction) into interactive learning (interactive teacher - learnerscommunity-natural environment, sources or other media), (c) Isolated learning patterns become networked learning (students can learn from anyone and from anywhere that can be contacted and obtained through the internet), (d) Passive learning patterns become activelooking learning (Active learning systems are looking for further strengthened by the learning model approach to science), (e) The pattern of self-learning becomes group learning (teambased), (f) The pattern of learning a single tool into multimedia-based learning, (g) The pattern of mass-based learning becomes the needs of customers (users) with strengthen the development of special potential students have, (h) The patternof learning single knowledge (mo nosdicipline) becomes plural science learning (multi discipline), (i) Passive learning pattern becomes critical learning (Mahuze, 2008). 
The curriculum required by the government in all schools is the 2013. Revised curriculum where teachers have the flexibility in developing their learning experiences for students. Not only that, teachers can also use learning approaches that are appropriate to the characteristics of the subjects, competencies, and subject matter, as well as the local conditions of each school. The 2013 Revised Curriculum demands high-level thinking skills that they want to build early on in elementary education (High Order Thingking Skills / HOTS). In other words, the ability of students is not limited to the taxonomy of the thought process because the level of thinking is freed up to the stage of creation which the level of creation is in accordance with his age (Ramos et al., 2013)

Cultural arts education is given in schools because of the uniqueness, meaningfulness, and usefulness of the development needs of students, which lies in providing aesthetic experience in the form of expressing / creating and appreciating activities through approaches: "learning with art," learning through art, "and" learning about art ". This role cannot be given by other subjects. Argues that art education aims to create a sense of beauty and the ability to process and appreciate art (creation and appreciation). Based on the curriculum, functions and objectives of art and culture education in junior high schools are designed to be able to develop attitudes, abilities and basic skills, creativity, sensitivity to a sense of beauty, and the development of student appreciation. Argues that the ideal concept of learning arts and culture should be able to develop aspects of artistic cognition, artistic appreciation, and creative experience in a balanced way, especially if it is related to the child's ability to be able to use students' thinking, creativity, taste, and creativity so that learning objectives which is expected to be achieved optimally. The effectiveness of learning art and culture can be seen from the learning product while its efficiency can be viewed in terms of time, cost, infrastructure, and learning visibility (Yee et al., 2015).

Lots of research results provide information to us about the importance of art education, especially music for children's development, here are some results of research from the Bulletin of the Council for Research in Music Education, the objectives of music art include the following: (1) Music education / art education, facilitates children's development in language and reading speed. (2) Music / art activities are very valuable for children's experiences in expression and so on. (3) Music / artistic activities foster the development of positive attitudes towards school and reduce the level of student absence from school. (4) Involvement in music / art activities directly enhances the development of creativity. (5) Music education / art education facilitates social development, self-adjustment, and intellectual development. From the explanation above, it turns out that music education is very important for children's development in the future. Learning the art of music is no longer an additional subject that can be eliminated at any time or just fill in spare time for children who take music lessons. Isn't education an important thing to help students develop their intellectual, emotional and potential within themselves? In addition, learning the art of music can help students improve their reading abilities because music has a positive relationship with phonological awareness (Veloo et al., 2013)

The learning model refers to the learning approach that will be used, including teaching objectives, stages in learning activities, learning environment, and classroom management. Choosing or determining the learning model is strongly influenced by the conditions of basic competence (KD), the objectives to be achieved in teaching, the nature of the material to be taught, and the ability of students. In learning arts and culture teachers often deliver material monotonously without using a varied learning model. For this reason, teachers must be wise in determining an appropriate model and which can create conducive classroom 
situations and conditions so that the learning process can take place in accordance with the expected goals (Mardhatillah, 2019).

The principles of accelerated learning are very suitable to be applied for learning the 2013 curriculum. The main demand in the 2013 curriculum is how a teacher changes his role as a facilitator and students turn into active learners. The principle of accelerated learning that involves the whole mind and body of students, creating, working together and positive emotions will make students active in learning. In learning accelerated learning students can be actively involved in order to achieve speed in mastering the lessons taught by the teacher through giving assignments at home and understanding the subject matter to be studied next, giving opportunities to ask questions, answer questions and explain each answer given, interaction, discussion with friends, so that students' level of reasoning and communication skills can be improved. Therefore, researchers use the development of accelerated learning models so that students are able to master group vocal material in practice, because in accelerated learning difficult subject matter is made easy, simple or not long-winded so it does not become saturated in learning.

Based on the results of Mariyana \& Zaman's research (2019), the design of multiple intelligence-based learning models effectively increases the potential of early childhood. Wijaya's research results (2018) show that the development of dual intelligence in elementary school students is a good momentum to increase the dimensions of attitudes, knowledge and skills of students.

Multiple intelligences exist in each individual, each individual will have one or more multiple intelligences at the highest level. Students will more easily understand the lesson if the material is presented in accordance with the prominent intelligence in students. For example, if a student stands out in musical intelligence, he will easily understand certain subjects, such as biology, if explained by incorporating musical elements into it. If students stand out in visual intelligence, it will be easier for them to grasp the lesson if explained using a variety of observable forms. Therefore, before teaching a teacher should have data about the level of multiple intelligences for each student or recognize what intelligence students have.

Most teachers do not know the theory of multiple intelligences and consequently they do not apply multiple intelligences in class learning, so it is proven that teachers who have a logical-mathematical domain tend to use their domains in learning activities. This can endanger students, because students will not be equipped with better learning models and learning becomes boring. According to Gardner, a teacher can develop learning strategies using other intelligence that he is not familiar with. The way to practice continuously even though the quality is not as good as the teacher who has a certain intelligence that stands out, but enough to teach students. Sternberg's theory says that intelligence is the ability of individuals to succeed in life by utilizing their strengths and compensating for their weaknesses.

Dual intelligence provides a platform and guide for teachers to use integrated learning strategies and activities to serve the different needs of students in learning style profiles and learning trends and through multiple intelligence learning models, students can learn the lesson more effectively.

The theory of multiple intelligences also impacts on a range of other learning activities, such as equipment, classroom management, and evaluation. Because it must use a variety of strategies according to student intelligence, of course it needs to be equipped with adequate equipment according to the strategy used. Likewise with class arrangement, it cannot only be 
arranged in one fixed position, marching from front to back. Sometimes the class needs to be arranged in a circle, in small groups, or it may be that the class needs to be emptied of the chair. In terms of evaluation also needs to vary according to the intelligence of students. An evaluation system that only uses written tests is not enough because it does not reveal diverse student intelligence. Gardner gave an example, there is a student who is intelligent in analyzing flora and fauna, and very creative in explaining to other students. But in an exam, with essay questions, the student always fails. The teacher did not understand the cause. It turns out that the student stands out in linguistic and natural intelligence, so he needs another way of evaluation, maybe verbally or asked to express it in another way (Mardhatillah, 2018).

Based on the background of the problems mentioned above, as a whole it can be concluded that in learning arts and culture the development of learning models is needed to help students achieve learning objectives. Therefore, researchers are very interested in developing accelerated learning models based on multiple intelligences in junior high school music art learning. Before developing the learning model, it is necessary to analyze the needs of accelerated learning models based on multiple intelligences in junior high school music learning.

\section{Research Methods}

This research is a type of research development or Research Development (R \& D). This research method is used to produce or perfect certain products by testing the effectiveness of the product. The product intended here is an ALMI learning model (a learning model based on accelerated learning based on multiple intelligences) which is expected to be able to improve student learning outcomes from cognitive, psychomotor, and affective aspects. This research will be carried out at Tebing Syahbandar Middle School and Dolok Masihol Middle School 1 Serdang Bedagai Regency. The subjects of this study were junior high school students, junior high school teachers (The following are RPP products, worksheets, and assessments used), and the Principal of SMP. Sampling was determined using stratified random sampling technique. Teacher samples were taken from 18 of 9 schools.

The object of this research is the thematic learning model and its tools that are used and used by junior high school teachers. The instruments used to collect data, are interview guides for principals, questionnaires for teachers, guidelines for observing learning models used so far, tests for student reasoning, and questionnaires. To analyze research data, descriptive analysis techniques are used.

\section{Discussion}

Based on the results of interviews with school principals, it can be described that school principals tend to have never done coaching specifically in the development of studentcentered learning models. The lack of coaching conducted by the school principal is due to inadequate understanding of school principals from learning models.

Therefore, $100 \%$ of school principals stated that they really expect research efforts to develop accelerated learning learning models and $100 \%$ of school principals stated that they would provide opportunities and support for teachers to take part in training programs to develop accelerated learning learning models. The results of the analysis of teacher response data indicate that learning models which are abruptly applied by the teachers in learning are less empowering of students' self potential. The learning models are (1) the assignment model, (2) the classical lecture model, (3) the question and answer discourse model, (4) the assignment 
model at home. (Mardhatillah, 2019).

To be able to apply the accelerated learning model properly, a teacher or facilitator must understand and apply the seven principles of accelerated learning (Meier; 2003). The principles are:

1. Learning involves the whole mind and body

2. Learning is creating, not consuming

3. Cooperation helps the learning process

4. Learning takes place on many levels simultaneously

5. Learning comes from doing the work itself

6. Positive emotions greatly help learning

7. The brain-image absorbs information directly and automatically.

The principles of accelerated learning are very suitable to be applied for learning the 2013 curriculum. The main demand in the 2013 curriculum is how a teacher changes his role as a facilitator and students turn into active learners. The principle of accelerated learning that involves the whole mind and body of students, creating, working together and positive emotions will make students active in learning.

One type of learning according to Gagne is learning to classify stimulus, or placing objects in certain groups that form a concept. Gagne's theory is in accordance with the results of research which states that accelerated learning is able to accommodate prior knowledge in achieving minimum standard mastery because accelerated learning focuses on understanding concepts and accommodating before building new knowledge. Merril's learning theory says that learning is a combination of some instructional knowledge from a behavioral and cognitive perspective.

The theory is in accordance with the results of research Safitri, Umamah, \& Sumardi (2019) states that accelerated learning \& discovery can help students to plant new knowledge, solve problems, and increase student competence for independent learning, constructivist, communication, collaboration, critical thinking and creative thinking. Brunner's theory states that humans as processors, thinkers and creators of information and learning are active processes that enable humans to discover new things beyond the information given to them. The theory is in accordance with the results of Khalandi \& Zoghi's (2017) research which states that accelerated learning is much more dynamic and has a significant effect on listening comprehension, listening, different learning styles in the learning process.

Landa's theory states that in humans there are two kinds of thought processes, namely algorithmic (liner, convergent and divergent) and heuristic (open, free to imagine or think) and Rogers's theory states that the process of eclectic learning is humanizing or achieving selfactualization. The theory of Landa and Rogers is in accordance with the results of Radler \& Bocianu's research (2017) which states that the accelerated learning theory (1) is oriented to collaboration, creativity, and continuous contact with the real world; (2) emphasizing active and holistic experience, designed to improve learning that can be achieved within a certain period of time where in terms of literature review, there are two concepts of accelerated learning, namely the time frame and approach to learning and teaching.

\section{Conclusion}

Based on the results of research and discussion presented previously, it can be concluded as follows. (1) School principals respond very important to the development of accelerated learning learning models. (2) The school principal has not provided coaching 
specifically to teachers in developing accelerated learning learning models. (3) The existence of accelerated learning model has not been found in the praxis of education. (4) The teachers do not have sufficient experience in implementing the accelerated learning learning model. Learning and learning assessment carried out so far is more product oriented rather than process.

This research has revealed that, there are no efforts of teachers, principals, and schools to develop accelerated learning models based on multiple intelligences. The model of its existence has never been used by teachers in learning. Therefore, suggestions are given as follows in order to be able to use the accelerated learning model based on multiple intelligences and in accordance with the daily context of students, so that learning in the classroom can be more effective and efficient.

\section{References}

Anzar, S. F., \& Mardhatillah, M. (2018). Analisis Kesulitan Belajar Siswa Pada Pembelajaran Bahasa Indonesia di Kelas V SD Negeri 20 Meulaboh Kabupaten Aceh Barat Tahun Ajaran 2015/2016. Bina Gogik: Jurnal Ilmiah Pendidikan Guru Sekolah Dasar, 4(1).

Mahuze, N. P. (2008). Pengembangan Bahan Ajar Berbasis Multimedia. Tersedia: Http://Www. Topazart.

Mardhatillah, S. M. S., Surjono, H. D., \& Muhtadi, A. (2019). Thematic Learning Based on Gender Equality and Value of Diversity to Strengthen Student National Character.

Mardhatillah, S. M. S., Verawati, V., Evianti, E., \& Pramuniati, I. (2019). Bahan Ajar Interaktif Berbasis Kearifan Lokal Melalui Pendekatan Saintifik Pada Pembelajaran Bahasa Inggris. Genta Mulia: Jurnal Ilmiah Pendidikan, 10(1). Info/Teks_teaching Mat/Flash/TutorialBahanAjarMultimedia. Pdf, 1884-1890.

Nasution, F., Setiawan, D., Lubis, W. 2020. The Influence of the NHT Assisted Media Model and Learning Motivation on Learning Outcomes of Citizenship Education. Britain International of Linguistics, Arts and Education (BIoLAE) Journal (2): 494507.

Ramos, J. L. S., Dolipas, B. B., \& Villamor, B. B. (2013). Higher Order Thinking Skills and Academic Performance in Physics of College Students: A Regression Analysis. Bulletin of the Museum Society of Maidugur.

Sitepu, T. 2019. Cooperative Model in Language Reasoning: Indonesian Language Teaching Materials in Teacher Training and Education Faculty of Muhammadiyah Sumatera Utara University. Britain International of Linguistics, Arts and Education (BIoLAE) Journal (1): 51-59.

Situmorang, I. G., Suyanti, R. D. M. (2010). Pengaruh Model Pembelajaran Inkuiri dengan Menggunakan Media Microsoft Frontpage dan Aktivitas Belajar Terhadap Hasil Belajar IPA Siswa pada Pokok Bahasan Zat Aditif Kelas VIII SMP.

Veloo, A., Komuji, M. M. A., \& Khalid, R. (2013). The Effects of Clinical Supervision on the Teaching Performance of Secondary School Teachers. Procedia - Social and Behavioral Sciences, 93(2002), 35-39. https://doi.org/10.1016/j.sbspro.2013.09.148

Wirdaningsih, W., \& Mardhatillah, M. (2016). Penerapan Media Audio-Visual Terhadap Keaktifan Pada Materi Hubungan Antara Sumber Daya Alam Dengan Lingkungan Siswa Kelas IV SD Negeri Pasi Teungoh Kecamatan Kaway XVI. Bina Gogik: Jurnal Ilmiah Pendidikan Guru Sekolah Dasar, 3(2).

Yee, M. H., Yunos, J. M., Othman, W., Hassan, R., Tee, T. K., \& Mohamad, M. M. (2015). Disparity of Learning Styles and Higher Order Thinking Skills among Technical Students. Procedia-Social and Behavioral Sciences. https://doi.org/10.1016/j.sbspro.2015.08.127 